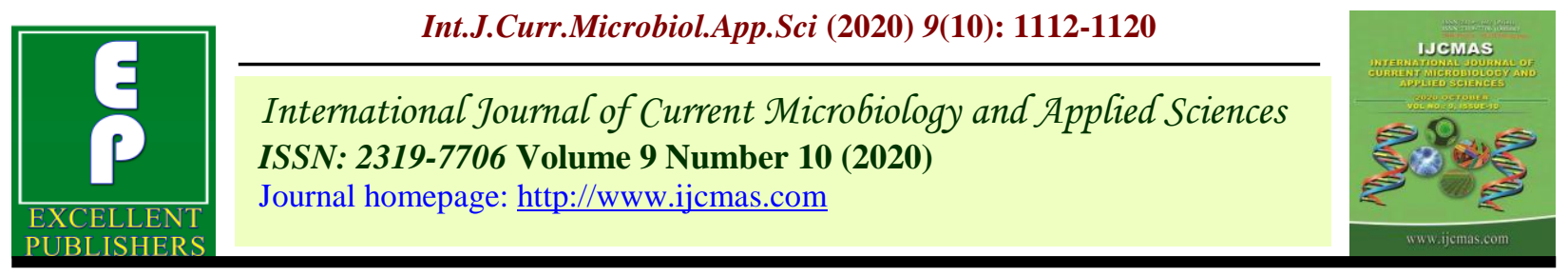

Original Research Article

https://doi.org/10.20546/ijcmas.2020.910.133

\title{
Effect of Nano Zinc and Silicon on Crop Growth and Yield of Rice (Oryza sativa L.)
}

\author{
K. Soumya ${ }^{1 *}$, G. K. Girijesh ${ }^{1}$, H. K. Veeranna ${ }^{1}$, \\ B. M. Dushyanthkumar ${ }^{2}$ and Sarvajna B. Salimath ${ }^{3}$
}

${ }^{1}$ Department of Agronomy, ${ }^{2}$ Department of Genetics and Plant Breeding, ${ }^{3}$ Department of Soil

Science and Soil Chemistry, University of Agricultural and Horticultural Sciences,

Shivmogga, India

*Corresponding author

\section{A B S T R A C T}

\section{Keywords}

Nano Zinc and

Silicon,

Rice, Foliar

application

Article Info

Accepted:

10 September 2020

Available Online:

10 October 2020
A field experiment "Effect of nano zinc and silicon on performance of wetland paddy (Oryza sativa L.)" has been conducted in Kharif (2019-20) at AHRS, Bavikere, UAHS, Shivamogga to see the effect of nano zinc and silicon on growth and yield of rice. The experiment consisted 12 treatments viz., seed treatment and foliar application of nano zinc and nano silicon either alone or in combination $\left(\mathrm{T}_{1}-\mathrm{T}_{6}\right)$, foliar application EDTA $\mathrm{ZnSO}_{4}(0.5 \%)$ at $40 \mathrm{DAT}\left(\mathrm{T}_{7}\right)$, foliar application of potassium silicate $(0.5 \%)$ at 40 DAT $\left(\mathrm{T}_{8}\right)$, foliar application EDTA $\mathrm{ZnSO}_{4}$ $(0.5 \%)$ at $40 \mathrm{DAT}+$ Potassium silicate $(0.5 \%)$ at $40 \mathrm{DAT}\left(\mathrm{T}_{9}\right)$, soil application of $\mathrm{ZnSO}_{4} @ 25 \mathrm{~kg} \mathrm{ha}^{-1}\left(\mathrm{~T}_{10}\right)$, rice hull ash @ $2 \mathrm{t} \mathrm{ha}^{-1}+\mathrm{RDF}\left(\mathrm{T}_{11}\right)$ and control $\left(\mathrm{T}_{12}\right)$ replicated thrice was laid out in completely randomized block design. Application of both zinc and silicon $\left(\mathrm{T}_{6}\right)$ in nano form as foliar @ $40 \mathrm{ppm}$ each at 40 DAT registered significantly higher No. of leaves, leaf area index, leaf area duration, total dry matter, crop growth rate, grain yield $\left(6034 \mathrm{~kg} \mathrm{ha}^{-1}\right)$ and straw yield (6693 $\mathrm{kg} \mathrm{ha}^{-1}$ ) closely followed by foliar application of nano zinc alone @ 40 ppm at 40 DAT.

\section{Introduction}

Rice is the staple food crop for more than half of the world's population and its cultivation secures livelihood for more than two billion people. In India rice is cultivated in an area of $43.39 \mathrm{~m}$ ha with annual production of 104.32 million tonnes and productivity $2404 \mathrm{~kg} \mathrm{ha}^{-1}$. To meet the growing demand of $130 \mathrm{~m}$ tonnes of milled rice by 2030 we need to increase the productivity by $4.03 \mathrm{t} \mathrm{ha}^{-1}$ thereby can maintain the present level of food sufficiency. Nutrient management is a key factor for any crop. Rice responds well to the good nutrient management. Any deficiency, specially at the critical stages leads to the maximum reduction in the final yield. Not only macro nutrients but micro and beneficial nutrients are crucial for plant growth. 
Among micronutrients, zinc is an essential micronutrient for humans, animals and plants. Zinc is directly involved in metabolism of auxins, nitrogen, and it also influences enzymatic activities, stabilization of chromosomal fraction. It also protects the plant cell from oxidative stress. Silicon is not an essential element but, it is known as the beneficial effect on cereals particularly in rice as it is a high siliciferous plant. Silicon is less mobile in the plant system hence its constant supply is required for sustainable production and $\mathrm{Si}$ improves the nutrient availability $(\mathrm{N}$, $\mathrm{P}, \mathrm{K}, \mathrm{Ca}, \mathrm{Mg}, \mathrm{S}$ and $\mathrm{Zn}$ ) and reduces the toxicity of $\mathrm{Fe}, \mathrm{Mn}, \mathrm{Al}$ and $\mathrm{Cd}$. Silicon is best known to protect the plant from biotic and abiotic stress.

One of the major constraints in rice production is its low nutrient use efficiency which is attributed due to the low absorption, leaching, runoff and lack of retention in the soil. Improving nutrient use efficiency in rice can be achieved by adopting effective innovative technologies.

Nanotechnology is one such technology which is engineered at molecular level and is the collective term for a range of technologies, techniques and processes that involve the manipulation of matter at the smallest scale. the Size of the nanomaterials is about 1 to 100 nanometers. In agriculture nano fertilizers are being studied as a way to increase nutrient efficiency over traditional fertilizers. Supply of chemical fertilizers in the form of nanoparticles in Indian agriculture has recently scattered the surface.

By use of nano fertilizers, the time and rate for the release of elements coincide and match plant nutritional requirements, thus plants can absorb maximum amount of nutrients and as a consequence, yield surges. hence these are also referred to as smart fertilizers.

\section{Materials and Methods}

A field experiment was conducted during Kharif in 2019-20 at Agricultural and Horticultural Research Station, Bavikere, UAHS, Shivamogga. The experiment consisted 12 treatments viz., seed treatment and foliar application of nano zinc and nano silicon either alone or in combination $\left(\mathrm{T}_{1}\right.$ $\mathrm{T}_{6}$ ), foliar application EDTA $\mathrm{ZnSO}_{4}(0.5 \%)$ at 40 DAT $\left(\mathrm{T}_{7}\right)$, foliar application of potassium silicate $(0.5 \%)$ at 40 DAT $\left(\mathrm{T}_{8}\right)$, foliar application EDTA $\mathrm{ZnSO}_{4}(0.5 \%)$ at $40 \mathrm{DAT}$ + Potassium silicate $(0.5 \%)$ at 40 DAT $\left(\mathrm{T}_{9}\right)$, soil application of $\mathrm{ZnSO}_{4} @ 25 \mathrm{~kg} \mathrm{ha}^{-1}\left(\mathrm{~T}_{10}\right)$, rice hull ash@2 $\mathrm{t} \mathrm{ha}{ }^{-1}+\mathrm{RDF}\left(\mathrm{T}_{11}\right)$ and control $\left(\mathrm{T}_{12}\right)$ replicated thrice was laid out in completely randomized block design. The variety sahyadrimegha was used in this experiment. Thirty days old seedlings were transplanted at two to three seedling per hill in the main field at $20 * 10$ spacing. Recommended dose of fertilizers (RDF) @ 100:50:50 kg N: $\mathrm{P}_{2} \mathrm{O}_{5}: \mathrm{K}_{2} \mathrm{O}+\mathrm{FYM} @ 10 \mathrm{t}$ $\mathrm{ha}^{-1}$ was common to all treatments. Observations on growth parameters viz., number of leaves hill ${ }^{-1}$, leaf area index, leaf area duration (days), total dry matter accumulation $\left(\mathrm{g}\right.$ plant $\left.{ }^{-1}\right)$, crop growth rate $(\mathrm{g}$ $\mathrm{m}^{-2}$ day $^{-1}$ ) were recorded at 30,60, 90 and at harvest whereas grain and straw yield were recorded by harvesting each plot separately. On the basis of grain and straw yield recorded in net plot, grain and straw yield per hectare was computed and was expressed in $\mathrm{kg} \mathrm{ha}^{-1}$.

\section{Results and Discussion}

\section{Total number of leaves hill'-1}

Leaf is known as kitchen in the plant system where synthesis of carbohydrates occurs and later it gets translocated to various plant parts. Among seed treatments, treatment with both nano zinc (100 ppm) and silicon (200 ppm) has recorded highest number of leaves (31.31) 
which was statistically superior over other treatments at 30 DAT. This was on par with seed treatment with nano zinc @ 100 ppm (30.82) and nano silicon@200 ppm (29.45) separately. Whereas, at 60, 90 DAT and at harvest treatment receiving foliar application of nano zinc and nano silicon each @ 40 ppm at 40 DAT registered maximum number of leaves (69.6, 76.0 and 36.7 at 60, 90 DAT and harvest, respectively) as against least with control as depicted in the Table 1 . However, treatments; $\mathrm{T}_{4}(66.9,75.30$ and 35.3 at 60, 90 and at harvest respectively), $\mathrm{T}_{3}(65.1,73.1$ and 37.7 at 60,90 and at harvest, respectively) and $T_{1}(65.0,73.2$ and 38.4 at 60,90 and at harvest, respectively) are numerically in the order of merit and statistically on par. Zinc protects the plant from ROS damage and controls the electrolyte leakage and improves germination and increase leaf production. Silicon on other hand protects the leaf from stress.

\section{Leaf area index}

Since leaf area index is the derivative of leaf area. Leaf area index estimated at different crop growth stages followed the same trend as that of leaf area. At 30 DAT significantly higher LAI of 1.10 was noted in seed treatment with both nano zinc (100 ppm) and nano silicon (200 ppm) closely followed by seed treatment with zinc (1.07) and nano silicon (1.05) alone which are on par and found statistically superior over rest of the treatments (Table 2).

At subsequent stages foliar application of both nano zinc and nano silicon each at 40 ppm at 40 DAT excelled over others by receiving LAI of 4.7, 6.6 and 1.8 closely followed by $(4.59,6.49$ and 1.79, respectively) foliar application of nano zinc alone @ 40 ppm at 40 DAT. Nano zinc foliar application was found statistically superior over conventional source at all stages.
Similarly, foliar application of nano silicon alone $(40 \mathrm{ppm})$ recorded statistically higher LAI than corresponding seed treatment and conventional potassium silicate treatments including rice hull ash application. The control plot registered significantly least LAI at all stages of crop growth $(0.80,5.08$ and 1.08). Similar results were reported by Torabian et al., (2016). Higher leaf area index may be due to higher nutrient uptake by the plants. Foliar application of nano form found to be a better method of application than seed treatment and soil application (Fageria et al., 1997).

\section{Leaf area duration (Days)}

Light interception occurs at varying degrees of efficiency by the plant canopy and this is associated with their LAI and its functionality. This is expressed in terms of leaf area duration (LAD). Leaf area duration is the mirror of leaf functionality and plants capacity to produce. It is an incentive for assimilation during the growing season and is more important in deciding the final yield and is also known as photosynthetic potential. Highest LAD was registered in the treatment receiving seed treatment with both nano zinc and silicon@ 100 and 200 ppm (16.45 days) at 30 DAT which was followed by seed treatment with nano zinc alone @ 100 ppm (16.0 days) and least was recorded in the control. Significant differences existed among the treatments as influenced by different forms and methods of zinc and silicon (Table 3). At the later stages, treatment with foliar application of nano zinc and silicon each @ $40 \mathrm{ppm}$ at 40 DAT recorded the highest leaf area duration $(87.05,170.06$ and 127.00 days between 30-60, 60-90 and 90-harvest, respectively) and on par results were found in the treatments with seed treatment with both nano zinc and silicon @ 100 and 200 ppm respectively (82.88 days) and seed treatment with nano zinc alone @ 100 ppm (82.45 days) 
between 30 to 60 DAT. Between 60-90 DAT and 90 DAT- harvest foliar application of nano zinc alone @ 40 ppm at 40 DAT (170.06 and 127.00 days between $60-90$ and 90 DAT harvest, respectively) was on par with the $T_{6}$. Control recorded least LAD at all the growth stages. Leaf area duration particularly from panicle emergence to spikelet formation is positively correlated $(0.78)$ to the final yield i.e. between 60 and 90 DAT. As the crop ages LAD also increases up to 90 DAT. The starch accumulated in rice grains is originated by carbohydrates assimilated in leaves after flowering or grain filling stage as well as carbohydrates stored in shoots. However, grain yield of rice is mainly affected by carbohydrate assimilation during ripening stages particularly, in high yielding varieties. Therefore, higher yield in treatments $\mathrm{T}_{6}, \mathrm{~T}_{4}$ and $\mathrm{T}_{3}$ is attributed to higher leaf area duration of 30-60 DAT. Overall, maximum LAD (between transplanting to harvesting) also noticed in $T_{6}$ followed by $T_{4}$. Involvement of zinc in chlorophyll formation by way of nutrient homeostasis in cytoplasm is also the reason for better photosynthesis. These results are in agreement with finding of Arvind and Prasad (2004). Lower yield in control plot was attributed to decrease in LAI and LAD at later stages as a result of less functional leaf and leaf senescence.

\section{Total dry matter production}

Highest total dry matter hill ${ }^{-1}$ of $3.88 \mathrm{~g}$ was obtained with combined seed treatment of nano zinc (100 ppm) and nano silicon (200 ppm) which was statistically higher over remaining treatments except seed treatment with nano zinc @ 100 ppm (3.64) and seed treatment with nano silicon (3.57) at 30 DAT (Table 4). Total dry matter accumulation per hill recorded at later stages of the crop revealed that the plants which received both zinc and silicon @ 40 ppm each as foliar at 40 DAT in nano form registered highest total dry matter $(19.85,55.27$ and $74.65 \mathrm{~g}$, respectively at 60, 90 and harvest, respectively). This was found on par with treatments: foliar application of nano zinc (40 ppm) at $40 \mathrm{DAT}$ (19.28 and $53.14 \mathrm{~g}$ ), conventional source of zinc and silicon in combination $\left(\mathrm{T}_{9}\right)$ (19.10 and $52.21 \mathrm{~g}$ ), combined seed treatment of both zinc $(100 \mathrm{ppm})$ and silicon $(200 \mathrm{ppm})$ (19 and $52.02 \mathrm{~g}$ ) both at 60 and 90 DAT, respectively. At $90 \mathrm{DAT} \mathrm{T}_{6}$ was also found on par with $\mathrm{T}_{2}$ (51.49 g). However, at harvest, foliar application of both zinc and silicon in nano form each @ 40 ppm at 40 DAT was excelled statistically over remaining treatments except with combined seed treatment with both zinc and silicon in nano form (71.6 g).Among seed treatment plots combined seed treatment with both zinc and silicon in nano form record significantly high total dry matter than nano zinc alone and on par with nano silicon alone. Similarly, foliar application of both zinc and silicon in nano form each at $40 \mathrm{ppm}$ at 40 DAT was statistically superior over nano silicon alone and on par with nano zinc application alone. Foliar application of nano zinc and silicon in combination and foliar spray of nano zinc alone was found better than corresponding seed treatment while, with regard to silicon alone, seed treatment recorded significantly higher total dry matter than corresponding foliar application. Irrespective of sources, it is noticed that treatment which involves both zinc and silicon registered higher total dry matter than soil application of either silicon or zinc. Zinc increased the auxin level in the plant which led to new shoots thus vigorous growth resulted in high dry matter production.

\section{Crop growth rate $\left(\mathrm{g} \mathrm{m}^{2} \mathrm{day}^{-1}\right)$}

Data recorded indicated that crop growth rate increased from date of transplanting to 90 DAT. Higher CGR was noticed during panicle emergence to complete fertilization stage of the crop (60-90 DAT) which is 
obvious due to the fact that all physiological activities at that stages are at high level (Table 5). During seedling stage (0-30 DAT) the maximum CGR $\left(6.47 \mathrm{~g} \mathrm{~m}^{2}\right.$ day $\left.^{-1}\right)$ was obtained in combined seed treatment with nano zinc (100 ppm) and nano silicon (200 ppm) closely followed by seed treatment with nano zinc@ 100 ppm (6.07 $\mathrm{g} \mathrm{m}^{2}$ day $\left.^{-1}\right)$ and seed treatment with nano silicon@200 ppm $\left(5.95 \mathrm{~g} \mathrm{~m}^{2}\right.$ day $\left.^{-1}\right)$ which are on par. At initial stages crop growth rate is in the order of merit seed treatment $>$ Combined foliar application of zinc and silicon > sole application of either zinc or silicon in nano form $>$ commercial source.

Crop growth rate recorded at later stages indicate the statistical superiority of foliar application of both zinc and silicon in nano form at $40 \mathrm{ppm}$ each at $40 \mathrm{DAT}$ as it registered higher CGR at all growth stages (27.83, 59.49 and $32.3 \mathrm{~g} \mathrm{~m} \mathrm{~m}^{2}$ day $^{-1}$, respectively at 30-60, 60-90 and 90 DAT harvest). Plots which received foliar spray of nano zinc @ 40 ppm at 40 DAT $(26.88,57.09$ and $30.77 \mathrm{~g} \mathrm{~m}^{2}$ day $^{-1}$ ) seed treatment with both zinc and silicon (25.57, 5.51 and $29.06 \mathrm{~g}$ $\mathrm{m}^{2}$ day $^{-1}$ ) and both zinc and silicon in conventional form $(25.91,56.70$ and $30.08 \mathrm{~g}$ $\mathrm{m}^{2}$ day $^{-1}$ ) are in order of merit and found on par with $\mathrm{T}_{6}$. However, during 90 DAT to harvest treatments did not differ significantly with respect to crop growth rate.

Table.1 Effect of application methods of nano zinc and silicon on number of leaves of paddy

\begin{tabular}{|c|c|c|c|c|}
\hline \multirow[t]{2}{*}{ Treatments } & \multicolumn{4}{|c|}{ Number of leaves } \\
\hline & $\begin{array}{c}30 \\
\text { DAT }\end{array}$ & $\begin{array}{c}60 \\
\text { DAT }\end{array}$ & $\begin{array}{c}90 \\
\text { DAT }\end{array}$ & $\begin{array}{c}\text { At } \\
\text { harvest }\end{array}$ \\
\hline$T_{1}:$ ST with nano zinc @ 100 ppm & 30.8 & 65.0 & 73.2 & 38.4 \\
\hline$T_{2}:$ ST with nano silicon @ 200 ppm & 29.5 & 58.3 & 69.8 & 39.6 \\
\hline $\begin{array}{l}\mathrm{T}_{3}: \mathrm{ST} \text { with nano zinc @ } 100 \text { ppm and nano silicon } \\
\text { @ 200ppm }\end{array}$ & 31.3 & 65.1 & 73.2 & 37.7 \\
\hline $\mathrm{T}_{4}:$ FA of nano zinc @ 40 ppm at 40 DAT & 25.1 & 66.9 & 75.3 & 35.3 \\
\hline $\mathrm{T}_{5}:$ FA of nano silicon @ 40 ppm at 40 DAT & 26.8 & 55.9 & 68.8 & 34.5 \\
\hline $\begin{array}{l}\text { T}_{6}: \text { FA of nano zinc and nano silicon each @ } 40 \text { ppm } \\
\text { at } 40 \text { DAT }\end{array}$ & 27.4 & 69.6 & 76.0 & 36.7 \\
\hline $\mathrm{T}_{7}:$ FA of EDTA $\mathrm{ZnSO}_{4}(0.5 \%)$ at 40 DAT & 26.3 & 60.7 & 70.1 & 36.2 \\
\hline $\mathrm{T}_{8}:$ FA of Potassium silicate $(0.5 \%)$ at 40 DAT & 24.9 & 57.7 & 67.3 & 32.6 \\
\hline $\begin{array}{l}\text { T}_{9} \text { : FA of } 0.5 \% \text { EDTA } \mathrm{ZnSO}_{4}+\text { Potassium silicate } \\
\text { at } 40 \text { DAT }(0.5 \%)\end{array}$ & 24.5 & 62.3 & 71.0 & 34.4 \\
\hline $\mathrm{T}_{10}:$ Soil application of $\mathrm{ZnSO}_{4} @ 25 \mathrm{~kg} \mathrm{ha}^{-1}$ & 23.2 & 56.1 & 66.7 & 30.9 \\
\hline $\mathbf{T}_{11}:$ Rice hull ash @ $2 \mathrm{tha}^{-1}$ & 23.9 & 57.7 & 65.4 & 32.5 \\
\hline $\mathbf{T}_{12}:$ Control & 22.2 & 53.7 & 64.6 & 31.2 \\
\hline S. Em+/- & 0.85 & 1.83 & 1.65 & 1.35 \\
\hline C.D. at $5 \%$ & 2.49 & 5.36 & 4.85 & 3.95 \\
\hline
\end{tabular}


Table.2 Effect of application methods of nano zinc and silicon on leaf area index of paddy

\begin{tabular}{|c|c|c|c|c|}
\hline \multirow[t]{2}{*}{ Treatments } & \multicolumn{4}{|c|}{ Leaf area index (LAI) } \\
\hline & $\begin{array}{l}30 \\
\text { DAT }\end{array}$ & $\begin{array}{c}\text { 60 } \\
\text { DAT }\end{array}$ & $\begin{array}{c}90 \\
\text { DAT }\end{array}$ & $\begin{array}{c}\text { At } \\
\text { harvest }\end{array}$ \\
\hline$T_{1}: S T$ with nano zinc @ 100 ppm & 1.1 & 4.5 & 6.3 & 1.7 \\
\hline$T_{2}:$ ST with nano silicon @ 200 ppm & 1.1 & 4.4 & 6.0 & 1.5 \\
\hline $\begin{array}{l}T_{3}: \text { ST with nano zinc @ } 100 \text { ppm and nano silicon } \\
\text { @ 200ppm }\end{array}$ & 1.1 & 4.5 & 6.3 & 1.7 \\
\hline $\mathrm{T}_{4}:$ FA of nano zinc @ 40 ppm at 40 DAT & 0.9 & 4.6 & 6.5 & 1.8 \\
\hline $\mathrm{T}_{5}$ : FA of nano silicon @ 40 ppm at $40 \mathrm{DAT}$ & 0.9 & 3.9 & 5.9 & 1.4 \\
\hline $\begin{array}{l}\text { T}_{6} \text { : FA of nano zinc and nano silicon each @ } 40 \text { ppm } \\
\text { at } 40 \text { DAT }\end{array}$ & 0.8 & 4.7 & 6.6 & 1.8 \\
\hline $\mathrm{T}_{7}:$ FA of EDTA $\mathrm{ZnSO}_{4}(0.5 \%)$ at $40 \mathrm{DAT}$ & 0.9 & 4.4 & 6.1 & 1.4 \\
\hline $\mathrm{T}_{8}:$ FA of Potassium silicate $(0.5 \%)$ at 40DAT & 0.8 & 3.9 & 5.9 & 1.2 \\
\hline $\begin{array}{l}\text { T}_{9}: \text { FA of } 0.5 \% \text { EDTA } \mathrm{ZnSO}_{4}+\text { Potassium silicate } \\
\text { at } 40 \text { DAT }(0.5 \%)\end{array}$ & 0.9 & 4.4 & 6.2 & 1.5 \\
\hline $\mathrm{T}_{10}:$ Soil application of $\mathrm{ZnSO}_{4} @ 25 \mathrm{~kg} \mathrm{ha}^{-1}$ & 1.0 & 3.3 & 5.6 & 1.1 \\
\hline $\mathbf{T}_{11}:$ Rice hull ash @ 2 t ha $^{-1}$ & 0.8 & 3.2 & 5.6 & 1.1 \\
\hline $\mathbf{T}_{12}:$ Control & 0.8 & 3.2 & 5.1 & 1.1 \\
\hline S.Em+/- & 0.02 & 0.13 & 0.11 & 0.09 \\
\hline C.D. at $5 \%$ & 0.05 & 0.39 & 0.34 & 0.25 \\
\hline
\end{tabular}

Table.3 Effect of application methods of nano zinc and silicon on leaf area duration of paddy

\begin{tabular}{|c|c|c|c|c|}
\hline \multirow[t]{2}{*}{ Treatments } & \multicolumn{4}{|c|}{ Leaf area duration (days) } \\
\hline & $\begin{array}{c}\text { 0-30 } \\
\text { DAT }\end{array}$ & $\begin{array}{l}\text { 30-60 } \\
\text { DAT }\end{array}$ & $\begin{array}{l}\text { 60-90 } \\
\text { DAT }\end{array}$ & $\begin{array}{l}90 \text { DAT- } \\
\text { harvest }\end{array}$ \\
\hline $\mathrm{T}_{1}:$ ST with nano zinc @ 100 ppm & 16.0 & 82.5 & 162.0 & 119.7 \\
\hline$T_{2}:$ ST with nano silicon @ 200 ppm & 15.7 & 79.6 & 155.5 & 112.2 \\
\hline$T_{3}: S T$ with nano zinc @100 ppm and nano silicon @ 200ppm & 16.5 & 82.9 & 162.6 & 120.0 \\
\hline $\mathrm{T}_{4}:$ FA of nano zinc @ 40 ppm at $40 \mathrm{DAT}$ & 12.7 & 81.8 & 166.1 & 124.2 \\
\hline$T_{5}:$ FA of nano silicon @ 40 ppm at 40 DAT & 13.0 & 73.1 & 147.8 & 110.1 \\
\hline $\begin{array}{l}\text { T6: FA of nano zinc and nano silicon each @ } 40 \text { ppm at } 40 \\
\text { DAT }\end{array}$ & 12.6 & 87.1 & 170.1 & 127.0 \\
\hline $\mathrm{T}_{7}:$ EDTA $\mathrm{ZnSO}_{4}(0.5 \%)$ FA at 40 DAT & 12.9 & 79.2 & 157.6 & 112.8 \\
\hline $\mathrm{T}_{8}:$ Potassium silicate FA $(0.5 \%)$ at 40 DAT & 12.6 & 76.0 & 146.6 & 106.6 \\
\hline $\begin{array}{l}\text { T9: } 0.5 \% \text { EDTA } \mathrm{ZnSO}_{4}+\text { Potassium silicate at } 40 \text { DAT } \\
(0.5 \%)\end{array}$ & 13.3 & 79.5 & 158.8 & 115.0 \\
\hline $\mathrm{T}_{10}:$ Soil application of $\mathrm{ZnSO}_{4} @ 25 \mathrm{~kg} \mathrm{ha}^{-1}$ & 14.8 & 57.2 & 134.5 & 101.5 \\
\hline $\mathbf{T}_{11}:$ Rice hull ash @ 2 t ha $^{-1}$ & 12.2 & 51.8 & 131.6 & 100.1 \\
\hline $\mathrm{T}_{12}:$ Control & 12.0 & 69.2 & 123.4 & 92.4 \\
\hline S.Em+/- & 0.65 & 3.77 & 7.31 & 5.63 \\
\hline C.D. at $5 \%$ & 1.92 & 11.07 & 21.44 & 16.51 \\
\hline
\end{tabular}


Table.4 Effect of application methods of nano zinc and silicon on total dry matter of paddy

\begin{tabular}{|c|c|c|c|c|}
\hline \multirow[t]{2}{*}{ Treatments } & \multicolumn{4}{|c|}{ Total dry matter $\left(\mathrm{g} \mathrm{plant}^{-1}\right)$} \\
\hline & $\begin{array}{c}\text { 30 } \\
\text { DAT }\end{array}$ & $\begin{array}{c}\text { 60 } \\
\text { DAT }\end{array}$ & $\begin{array}{c}90 \\
\text { DAT }\end{array}$ & $\begin{array}{c}\text { At } \\
\text { harvest }\end{array}$ \\
\hline$T_{1}:$ ST with nano zinc @ 100 ppm & 3.64 & 18.59 & 49.51 & 65.44 \\
\hline$T_{2}: S T$ with nano silicon @ 200 ppm & 3.57 & 18.19 & 51.49 & 68.93 \\
\hline$T_{3}: S T$ with nano zinc @100 ppm and nano silicon @ 200ppm & 3.88 & 19.00 & 52.02 & 70.34 \\
\hline $\mathrm{T}_{4}: \mathrm{FA}$ of nano zinc @ $40 \mathrm{ppm}$ at $40 \mathrm{DAT}$ & 3.16 & 19.28 & 53.14 & 71.60 \\
\hline$T_{5}:$ FA of nano silicon @ 40 ppm at 40 DAT & 3.13 & 17.02 & 48.18 & 62.91 \\
\hline $\begin{array}{l}\text { T}_{6}: \text { FA of nano zinc and nano silicon each @ } 40 \text { ppm at } 40 \\
\text { DAT }\end{array}$ & 3.15 & 19.85 & 55.27 & 74.65 \\
\hline $\mathrm{T}_{7}: \mathrm{FA}$ of EDTA $\mathrm{ZnSO}_{4}(0.5 \%)$ at $40 \mathrm{DAT}$ & 3.03 & 18.21 & 49.77 & 66.92 \\
\hline$T_{8}:$ FA of Potassium silicate $(0.5 \%)$ at 40 DAT & 3.12 & 16.60 & 48.09 & 63.06 \\
\hline $\begin{array}{l}\text { T9: FA of } 0.5 \% \text { EDTA } \mathrm{ZnSO}_{4}+\text { Potassium silicate at } 40 \text { DAT } \\
(0.5 \%)\end{array}$ & 2.89 & 19.10 & 52.21 & 70.59 \\
\hline $\mathrm{T}_{10}:$ Soil application of $\mathrm{ZnSO}_{4} @ 25 \mathrm{~kg} \mathrm{ha}^{-1}$ & 3.29 & 16.25 & 47.16 & 62.86 \\
\hline $\mathbf{T}_{11}$ : Rice hull ash @ 2 t ha $^{-1}$ & 3.08 & 15.89 & 46.68 & 61.88 \\
\hline $\mathbf{T}_{12}$ : Control & 2.57 & 15.04 & 44.71 & 59.18 \\
\hline S.Em+/- & 0.19 & 0.44 & 1.48 & 1.25 \\
\hline C.D. at $5 \%$ & 0.57 & 1.30 & 4.33 & 3.66 \\
\hline
\end{tabular}

Table.5 Effect of application methods of nano zinc and silicon on crop growth rate of paddy

\begin{tabular}{|c|c|c|c|c|}
\hline \multirow[t]{2}{*}{ Treatments } & \multicolumn{4}{|c|}{ CGR $\left(g / m^{2} /\right.$ day $)$} \\
\hline & $\begin{array}{l}\text { 0-30 } \\
\text { DAT }\end{array}$ & $\begin{array}{l}\text { 30-60 } \\
\text { DAT }\end{array}$ & $\begin{array}{l}60-90 \\
\text { DAT }\end{array}$ & $\begin{array}{l}\text { 90DAS -at } \\
\text { harvest }\end{array}$ \\
\hline$T_{1}: S T$ with nano zinc @ 100 ppm & 6.07 & 25.41 & 54.31 & 28.55 \\
\hline$T_{2}: S T$ with nano silicon @ 200 ppm & 5.95 & 24.36 & 51.53 & 26.09 \\
\hline $\begin{array}{l}\mathrm{T}_{3}: \mathrm{ST} \text { with nano zinc @100 ppm and nano } \\
\text { silicon @ 200ppm }\end{array}$ & 6.47 & 25.57 & 55.51 & 29.06 \\
\hline$T_{4}:$ FA of nano zinc @ 40 ppm at 40 DAT & 5.26 & 26.88 & 57.09 & 30.77 \\
\hline $\mathrm{T}_{5}:$ FA of nano silicon @ $40 \mathrm{ppm}$ at $40 \mathrm{DAT}$ & 5.22 & 22.98 & 51.93 & 24.55 \\
\hline $\begin{array}{l}\text { T6: FA of nano zinc and nano silicon each @ } \\
40 \text { ppm at } 40 \mathrm{DAT}\end{array}$ & 5.25 & 27.83 & 59.49 & 32.30 \\
\hline $\mathrm{T}_{7}:$ FA of EDTA $\mathrm{ZnSO}_{4}(0.5 \%)$ at 40 DAT & 5.04 & 25.31 & 53.09 & 27.25 \\
\hline $\mathrm{T}_{8}$ : FA of Potassium silicate $(0.5 \%)$ at 40 DAT & 5.20 & 22.47 & 52.46 & 24.94 \\
\hline $\begin{array}{l}\mathrm{T}_{9}: \text { FA of } 0.5 \% \text { EDTA } \mathrm{ZnSO}_{4}+\text { Potassium } \\
\text { silicate at } 40 \mathrm{DAT}(0.5 \%)\end{array}$ & 4.81 & 25.91 & 56.70 & 30.08 \\
\hline $\mathrm{T}_{10}$ : Soil application of $\mathrm{ZnSO}_{4} @ 25 \mathrm{~kg} \mathrm{ha}^{-1}$ & 5.48 & 21.61 & 50.85 & 26.16 \\
\hline $\mathbf{T}_{11}:$ Rice hull ash @ $2 \mathrm{t} \mathrm{ha}^{-1}$ & 5.13 & 21.90 & 49.66 & 25.32 \\
\hline $\mathrm{T}_{12}$ : Control & 4.29 & 20.79 & 47.45 & 24.10 \\
\hline S.Em+/- & 0.32 & 0.86 & 1.82 & 2.95 \\
\hline C.D. at $5 \%$ & 0.94 & 2.51 & 5.33 & 8.66 \\
\hline
\end{tabular}


Among zinc application treatments, foliar application of nano zinc @ 40 ppm at 40 DAT has recorded significantly higher CGR than corresponding seed treatment and conventional form up to 90 DAT. However, during 90 DAT to harvest treatment are on par. Whereas, irrespective of source and form, silicon application alone did not improve the CGR. Nano form > conventional, foliar > seed treatment with both zinc and silicon > silicon or zinc application alone are in the order of merit. Control treatment registered significantly least crop growth rate at all crop growth stages. Crop growth rate (CGR) is a simple crop index of rate of dry matter production. At all growth stages, crop growth rate differed significantly.

Application of nano zinc and silicon as seed treatment increased CGR at initial stages due to positive role of silicon in root growth that improves early growth (Meena and Kumar, 2017). Whereas, at later stages, foliar application particularly zinc increases the biomass production, green leaves per plant, leaf area, leaf area index and leaf area duration (Singh and Kumar, 2017). Higher crop growth rate in these treatments is due to higher total dry matter accumulated as CGR is the derivative of dry matter. Uyeda (1991) opined that changes in the shape of a material into the nano size will change the characteristics of the physical, chemical, biological and catalytic activity of the material. The shoot weight is directly correlated with leaf area and weight of culm and leaf. Thus, crop growth rate and dry mater production can be interpreted in terms of photosynthetic apparatus like leaf area, leaf area index and leaf area duration.

\section{Grain and straw yield ( $\left.\mathrm{kg} \mathrm{ha}^{-1}\right)$}

The treatments which received both zinc and silicon $\left(\mathrm{T}_{6}\right)$ in nano form as foliar @ 40 ppm each at 40 DAT registered the highest grain
(6034 kg ha $\left.{ }^{-1}\right)$ and straw yield (6693 $\left.\mathrm{kg} \mathrm{ha}^{-1}\right)$ which was significantly superior over rest of the treatments except with treatments; foliar application of nano zinc alone @ 40 ppm at 40 DAT $\left(5720,6131 \mathrm{~kg} \mathrm{ha}^{-1}\right.$ of grain and straw yield respectively).

Control plot treatment registered least grain yield (4274 $\mathrm{kg} \mathrm{ha}^{-1}$ ) and straw yield (4550 kg $\left.\mathrm{ha}^{-1}\right)$. Grain yield is a function of yield components viz., productive tillers, panicles, test weight, chaffiness and grain yield per plant. Whereas, straw yield dependent on the biomass. The increase in grain yield due to combined application of nano particles of $\mathrm{Zn}$ and $\mathrm{Si}$ as foliar at $40 \mathrm{ppm}$ at $40 \mathrm{DAT}\left(\mathrm{T}_{6}\right)$ is mainly attributed to higher yield components and also stimulation effect of zinc and silicon in reducing biotic and abiotic stress. Nano zinc resulted in significant increase in the grains per panicle which is directly related to grain yield per hill. Fischer and Kohn (2006) have also reported higher grain per panicle with nano zinc oxide application. While, silicon helps in improving the translocation of the metabolites to the grains and also decreases the transpiration rate as a result grain yield per plant is increased significantly. Wattanapayapkul et al., (2011) also reported 19 to 43 per cent of higher yield due to silicon application over control. Silicon enhances the straw yield and helps in upright orientation of leaves and thereby reduces the mutual shading of leaves and indirectly increases the photosynthetic area (Osuna et al., 1991). Higher nutrient uptake takes a lion share in increasing straw yield by 47 per cent (Rana and Kashif, 2014).

\section{References}

Aravind, P. and Prasad, M. N. V., 2004, Zinc protects chloroplasts and associated photochemical functions in cadmium exposed (Ceratophyllum demersum L.), a freshwater macrophyte. Plant Sci., 
166: 1321-1327.

Fageria, N. K., Baligar, V. C. and Jones, C. A., 1997, Growth and mineral nutrition of field crops, 2nd edition. New York: Marcel Dekker, Inc.

Fischer, R. A.and Kohn, G. D., 2006, The relationship of grain yield to vegetative growth and post-flowering leaf area in wheat crop under conditions of limited soil moisture. Aust. J. Agric. Res., 17: 281-95.

Meena, D. S and Kumar, B. N. A., 2017, Bio efficacy of nano zinc sulphide $(\mathrm{ZnS})$ on growth and yield of sunflower (Helianthus annuus L.) and nutrient status in the soil. Int. J. Agr. Sci., 9(6): 3795-3798.

Osuna, F. J., Canizalez, S K., Datta, D. and Bonman, J. M., 1991, Nitrogen form and silicon nutrition effects on resistance to blast disease of rice. $P l$. Soil., 135: 223-231.

Rana, W. K. and Kashif, S. R., 2014, Effect of different zinc sources and methods of application on rice yield and nutrients concentration in rice grain and straw. $J$. Environ. Agric. Sci., 1(3): 1-5

Singh, M, D. and Kumar, B, N, A., 2017, Bio efficacy of nano zinc sulphide $(\mathrm{ZnS})$ on growth and yield of sunflower (Helianthus annuus L.) and nutrient status in the soil. Int. J. Agric. Sci., 9(6): 3795-3798.

Torabian, S., Zahedi, M. and Khoshgoftar, A, H., 2016, Effects of foliar spray of two kinds of zinc oxide on the growth and ion concentration of sunflower cultivars under salt stress. J. Plant Nutr., 39(2): 172-180.

Uyeda, R., 1991, Studies of ultrafine particles in japan: Crystallography methods of preparation and technological applications. Progr. Mater. Sci., 35: 195.

Wattanapayapkul, W., Polthanee, A., Siri, B., Bhadalung, N. N. and Promkhumbut, A., 2011, Effect of silicon in suppressing blast disease and increasing grain yield of organic rice in northeast Thailand. Indian. J. Pl Path., 5: 134-45.

\section{How to cite this article:}

Soumya, K., G. K. Girijesh, H. K. Veeranna, B. M. Dushyanthkumar and Sarvajna B. Salimath. 2020. Effect of Nano Zinc and Silicon on Crop Growth and Yield of Rice (Oryza sativa L.). Int.J.Curr.Microbiol.App.Sci. 9(10): 1112-1120. doi: https://doi.org/10.20546/ijcmas.2020.910.133 